\title{
Effect of tillage and fertilizer doses on growth and growth indices of soybean (Glycine max L.) under conservation tillage systems
}

\author{
Shilpa $\times$ \\ Department of Agronomy College of Agriculture CSKHPKV, Palampur, Himachal Pradesh \\ Janardan Singh \\ Department of Agronomy College of Agriculture CSKHPKV, Palampur Himachal Pradesh \\ Ankit Saini \\ Department of Agronomy College of Agriculture CSKHPKV, Palampur Himachal Pradesh \\ Tarun Sharma \\ Department of Agronomy College of Agriculture CSKHPKV, Palampur Himachal Pradesh \\ Parita \\ Department of Agronomy College of Agriculture CSKHPKV, Palampur, Himachal Pradesh
}

\begin{tabular}{|c|c|}
\hline ARTICLE INFO & ABSTRACT \\
\hline $\begin{array}{l}\text { Received : } 19 \text { May } 2021 \\
\text { Revised : } 20 \text { July } 2021 \\
\text { Accepted : } 14 \text { September } 2021 \\
\text { Available online: } 9 \text { December } 2021 \\
\text { Key Words: } \\
\text { Conventional tillage } \\
\text { Crop residues } \\
\text { Efficiency } \\
\text { Fertilizer } \\
\text { Growth indices } \\
\text { Minimum Tillage }\end{array}$ & $\begin{array}{l}\text { A field experiment was conducted during kharif season of } 2019 \text { at the Research } \\
\text { Farm, Department of Agronomy, CSKHPKV, Palampur to study the effect of } \\
\text { tillage and fertilizer doses on growth and growth indices of soybean under } \\
\text { conservation tillage systems. The experiment consisted of twelve treatment } \\
\text { combinations which included three tillage systems minimum tillage, minimum } \\
\text { tillage with crop residue and conventional tillage and four fertility levels viz; } 25 \\
\text { \% recommended dose of fertilizer (RDF), } 50 \%(\text { RDF), } 75 \% \text { RDF and } 100 \% \\
\text { RDF and which were tested in split plot design with tillage system in main plots } \\
\text { and fertility levels in sub plots. The soil texture of experimental site was silty clay } \\
\text { loam. Minimum tillage along with crop residues }\left(\mathrm{T}_{2}\right) \text { recorded significantly taller } \\
\text { plants and higher dry matter accumulation followed by conventional tillage. } \\
\text { Absolute growth rate, crop growth rate, dry matter efficiency, relative growth } \\
\text { rate and unit area efficiency were significantly higher with minimum tillage }+ \\
\text { crop residue treatment. Application of } 100 \% \text { followed by } 75 \% \text { recommended } \\
\text { dose of fertilizer resulted in significantly higher growth parameters and growth } \\
\text { indices. }\end{array}$ \\
\hline
\end{tabular}

\section{Introduction}

Soybean (Glycine max L.) also known as 'golden bean' is the second most important Kharif oilseed crop being grown in various parts of the state. It is cultivated as sole crop as well as an intercrop with maize, ragi etc. In India, area under soybean crop is 11.4 million hectares with production and productivity of 13.5 million tonnes and 1185 kilogram per hectares, respectively(Anonymous 2019). The area under soybean crop in Himachal is 0.55 thousand hectares with an average production of 931 tonnes (Anonymous 2018). The conventional tillage methods are easy to adopt and provide clean cultivation. They have been used to

grow many crops including soybean since a long time but are consideredas expensive operations in terms of work and fuel consumption. Conventional tillage leads to high erosion hazards. It completely inverts the soil and buries crop residues, making the land much more exposed to erosive forces of wind and water. Erosion eventually reduces the productivity of land (Mathew et al., 2012). The alternate for all these problems is conservation tillage. Tillage systems such as ridge-till, minimum tillage and no-till leave more crop residues and offer greater erosion control. Fuel and labour requirements are also less with conservation tillage. 
To solve all said problems considerable attention has been diverted towards conservation tillage methods i.e. minimum tillage or reduced tillage or zero tillage. On the other hand, plant residues used as mulching not only cover the soil surface but also help to supply plant nutrients on decomposition by micro-organism.

Besides appropriate selection of tillage practices, the improvement in average yield per hectare can be obtained if soil fertility is maintained through proper dose and application method of fertilizers. Application of fertilizers is widely recognized as a way of improving crop productivity and sustainability. Imbalanced use of chemical fertilizers deteriorates the soil health. It is, therefore, necessary to develop a suitable production system with maximum productivity and minimum environmental pollution.

\section{Material and Methods}

A field experiment was conducted during kharif season of 2019 to study the effect of tillage and fertilizer doses on growth and growth indices of soybean at the Research Farm, Department of Agronomy, CSK HPKV, Palampur located at $32^{\circ} 6^{\prime} \mathrm{N}$ latitude, $76^{\circ} 3^{\circ} \mathrm{E}$ longitude and at an altitude of $1290.8 \mathrm{~m}$ above mean sea level.

Each treatment was located randomly in plots by using random number table and replicated thrice. The soil of experimental area was found silty clay loam in nature having $\mathrm{pH} 4.5$. The soil values were found low in nitrogen $(218 \mathrm{~kg} / \mathrm{ha})$, medium in phosphorus $(11.4 \mathrm{~kg} / \mathrm{ha})$ and high in potassium (240 kg/ha) during the course of study.

The meteorological data during the crop season revealed that the weekly maximum and minimum temperature ranged from 23.57 to $31.64{ }^{\circ} \mathrm{C}$ and 10.14 to $20.39{ }^{\circ} \mathrm{C}$ respectively. The mean relative humidity ranged from 51.79 to $91.57 \%$ and total rainfall was $197.80 \mathrm{~mm}$. The total sunshine hours were 94.16 (Anonymous 2021, Crop weather outlook).The experiment was laid out in split plot design with three replications. There were twelve treatment combinations which included three tillage systems minimum tillage, minimum tillage with mustard crop residue ( $3 \mathrm{t} / \mathrm{ha})$ and conventional tillage and four fertility levels viz; $25 \%$ recommended dose of fertilizer (RDF) , $50 \%(\mathrm{RDF})$ , $75 \% \mathrm{RDF}$ and $100 \% \mathrm{RDF}$, which were tested in split plot design with tillage system in main plots and fertility levels in sub plots. 'Harit Soya' was usedas test variety sown at $45 \mathrm{~cm} \times 10 \mathrm{~cm}$ spacing. The size of each plot was $4.5 \times 3.0 \mathrm{~m}^{2}$. Seeds of soybean were treated with bavistin @ $2.5 \mathrm{~g} / \mathrm{kg}$ of seed before sowing to protect from seed borne diseases. Recommended dose of fertilizers (20:60:40) (Package of practices, kharif, 2019) in the state was applied @ $25 \%, 50 \%, 75 \%$ and 100 $\%$ at the time of sowing. The nutrients were applied through urea, single super phosphate and muriate of potash respectively. Pendimethalin (Stomp 30 EC) was applied@4.51/ha within 48 hours of sowing for weed control. Plant height and dry matter accumulation were recorded at thirty days interval of each monthfor evaluating different growth indices. Five randomly selected plants in each plot were tagged for height measurement. Plant height was measured in centimetres from the base of plant to the top. The average height of the five plants were calculated and expressed as plant height. For dry matter accumulation, five plant samples from the sampling row next to border rows were taken from each plot at 30 days interval up to harvest. The plants were cut close to the ground and kept in oven at $70^{\circ} \mathrm{C}$ for 3 hours after sun drying of samples. Plant samples were weighed down when they attained constant weight and the dry weight was calculated and expressed as g/ plant.

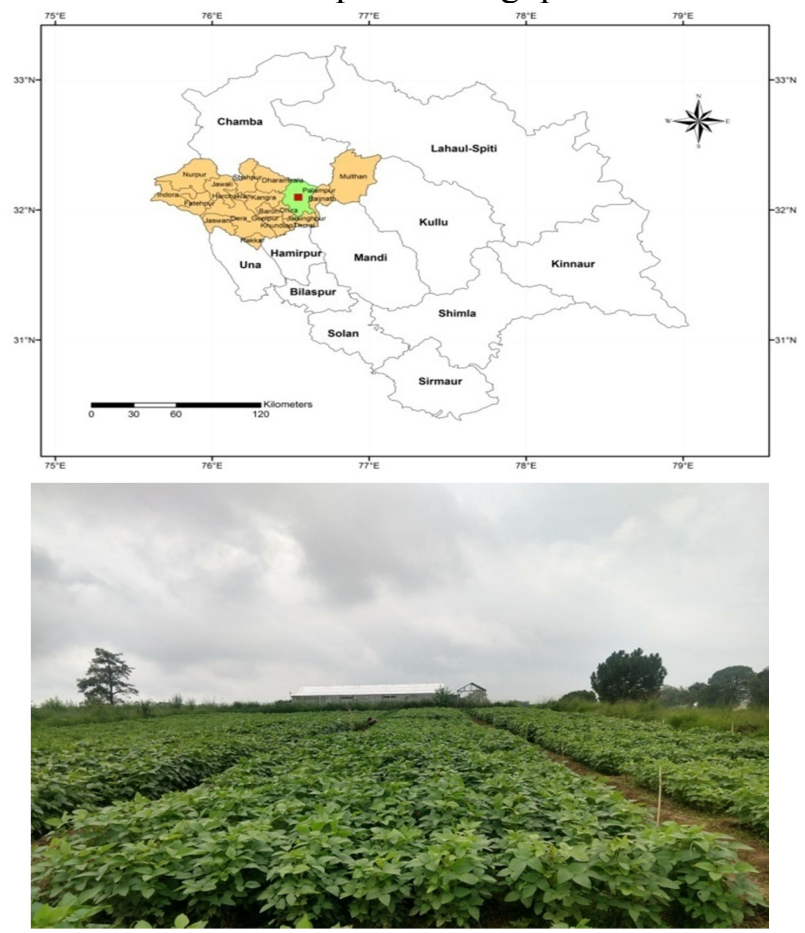

Figure 1: Sampling locations $\left(32^{\circ} 6^{\circ} \mathrm{N}, 7^{\circ} 3^{`} \mathrm{E}\right)$ 
The following formulae were used to determine various growth indices:

Absolute growth rate was determined by using the formula given by Radford (1967).

$$
\operatorname{AGR}(\mathrm{cm} / \mathrm{day})=\frac{h 2-h 1}{t 2-t 1}
$$

Where, $h_{1}$ and $h_{2}$ were plant height at $t_{1}$ and $t_{2}$ times, respectively.

Crop growth rate was determined by using the formula given by Watson (1956):

$$
\operatorname{CGR}(g / p l a n t / \text { day })=\frac{w 2-w 1}{p(t 2-t 1)}
$$

Where, $\mathrm{w}_{1}$ and $\mathrm{w}_{2}$ were whole plant dry weight at $\mathrm{t}_{1}$ and $t_{2}$ time, respectively. $p$ is the ground area on which $\mathrm{w}_{1}$ and $\mathrm{w}_{2}$ were recorded.

Relative growth rate was determined by using the formula given by Fisher (1921).

$$
\operatorname{RGR}(g / g / d a y)=\frac{(\log w 2-\log w 1)}{t 2-t 1}
$$

Where, $\mathrm{w}_{1}$ and $\mathrm{w}_{2}$ were dry weight of whole plant at times $t_{1}$ and $t_{2}$ respectively.

Dry matter efficiency expressed as the percent of dry matter accumulated in the grain from the total dry matter produced over the crop growth period.

Dry matterefficiency $(\%)=\frac{\text { GrainYield }(\mathrm{kg} / \mathrm{ha})}{\text { BiologicalYield }(\mathrm{kg} / \mathrm{ha})} \times \frac{100}{\text { Durationofcrop }(\text { days })}$

Unit area efficiency expressed as the quantum of grain yield produced over a unit land area for a specified crop growth period $(\mathrm{kg} / \mathrm{ha} /$ day $)$.

Unitareaefficiency $(\%)=\frac{\text { GrainYield }\left(\frac{\mathrm{kg}}{\mathrm{ha}}\right)}{\operatorname{Landarea}(\text { ha })} \times \frac{1}{\text { Durationofcrop }(\text { days })}$

\section{Results and Discussion}

\section{Growth}

Plant Height: Different tillage treatments significantly affected the plant height at 30,60 days after sowing and at harvest. Minimum tillage along with mustard residues $\left(\mathrm{T}_{2}\right)$ recorded tallest plants $(91.52 \mathrm{~cm})$ of soybean followed by conventional tillage $\left(\mathrm{T}_{3}\right)(88.54 \mathrm{~cm})$ and minimum tillage $\left(\mathrm{T}_{1}\right)$ $(86.60 \mathrm{~cm})$ respectively at all the growth stages. Among different fertilizer doses, tallest plants $(91.97 \mathrm{~cm})$ were recorded with $100 \%$ NPK $\left(F_{4}\right)$ followed by $75\left(\mathrm{~F}_{3}\right)(89.43 \mathrm{~cm})$ and $50 \% \mathrm{NPK}\left(\mathrm{F}_{2}\right)$ $(87.43 \mathrm{~cm})$. Significantly, shorter plants $(86.31 \mathrm{~cm})$ were recorded with $25 \%$ NPK $\left(\mathrm{F}_{1}\right)$ fertilizer dose. Enhancement in soybean growth under minimum tillage with residue treatment might be due the reason that the soil water was conserved and used for soybean growth rather than evaporation. Similar results were found by Sikka et al. (2018) in soybean. They reported that plant height tended to increase with the application of wheat straw mulch over no mulch treatment. Another reason for enhancement in soybean growth was the result of soil water being used for plant growth and yield rather than the evaporation of soil water.

Dry Matter Accumulation: Significantly higher dry matter accumulation (44.93 g/plant) was recorded in $\mathrm{T}_{2}$ followed by $\mathrm{T}_{3}(35.91 \mathrm{~g} /$ plant $)$ and $\mathrm{T}_{1}(35.71$ $\mathrm{g} / \mathrm{plant})$ at all the growth stages. Different fertilizer doses significantly affected the dry matter accumulation of soybean at 30,60, and 90 days after sowing.Similar results were found by Singh et al., 2018 in soybean.Different fertilizer doses significantly affected the dry matter accumulation. Highest dry matter accumulation (43.46 g/plant) was recorded with $\mathrm{F}_{4}$ followed by $\mathrm{F}_{3}(40.42 \mathrm{~g} /$ plant $)$ and $\mathrm{F}_{2}$ (37.42 g/plant). Significantly, lower accumulation of dry matter (34.09 g/plant) was recorded with $25 \%$ NPK $\left(\mathrm{F}_{1}\right)$ fertilizer dose. Higher dry matter accumulation of soybean with minimum tillage and crop residues might be due to availability of moisture for longer period without disturbing the soil, which results in better crop growth and supply of nutrients in adequate amount. Similar results were found by Singh et al., (2018). They reported that mulching enhance the moisture availability of soil. Sufficient moisture in soil, helped plant to extract sufficient nutrients from root zone which enhanced the overall health of plant.

\section{Growth Indices}

Absolute Growth Rate: Different tillage treatments significantly affected the absolute growth rate at different stages of crop growth. Among them, $\mathrm{T}_{2}$ significantly recorded higher absolute growth rate $(1.504 \mathrm{~cm} /$ day $)$ followed by $\mathrm{T}_{3}(1.492 \mathrm{~cm} /$ day $)$ and $\mathrm{T}_{1}(1.458 \mathrm{~cm} /$ day $)$ at 30 and 60 days after sowing. Different fertilizer doses significantly affected the absolute growth rate of soybean at 30 and 60 days after sowing .Highest absolute growth rate $(1.581$ $\mathrm{cm} /$ day) was recorded with $\mathrm{F}_{4}$ followed by $\mathrm{F}_{3}(1.520$ $\mathrm{cm} /$ day). Retention of crop residues on minimum tillage plots in addition to normal application of chemical fertilizers enhances growth indices of crop 
Table 1: Effect of tillage and fertilizer doses on plant height, dry matter accumulation, dry matter efficiency and unit area efficiency of soybean.

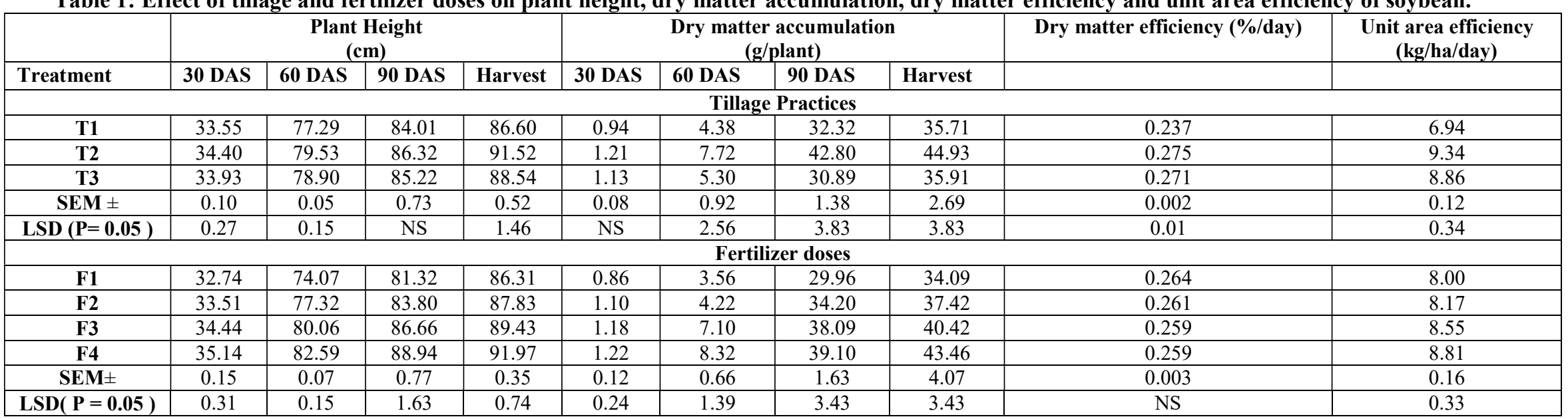

*T1= Minimum Tillage, $T 2=$ Minimum Tillage + Crop Residue, $T 3=$ Conventional Tillage

$* F 1=25 \%$ NPK, F2=50\% NPK, F3 $=75 \%$ NPK, F4 $=100 \%$ NPK

$* D A S=$ Days after sowing

Table 2: Effect of tillage and fertilizer doses on growth indices of soybean.

\begin{tabular}{|c|c|c|c|c|c|c|c|c|c|c|c|c|}
\hline & \multicolumn{4}{|c|}{ Absolute Growth Rate (cm/day) } & \multicolumn{4}{|c|}{ Crop Growth Rate (g/plant/day) } & \multicolumn{4}{|c|}{ Relative Growth Rate (g/g/day) } \\
\hline Treatment & 30 DAS & 60 DAS & 90 DAS & Harvest & 30 DAS & 60 DAS & 90 DAS & Harvest & 30 DAS & 60 DAS & 90 DAS & Harvest \\
\hline \multicolumn{13}{|c|}{ Tillage Practices } \\
\hline T1 & 1.118 & 1.458 & 0.225 & 0.086 & 0.031 & 0.115 & 0.931 & 0.113 & -0.0015 & 0.021 & 0.029 & 0.0013 \\
\hline T2 & 1.147 & 1.504 & 0.227 & 0.173 & 0.040 & 0.217 & 1.169 & 0.071 & 0.0023 & 0.025 & 0.025 & 0.0007 \\
\hline T3 & 1.131 & 1.492 & 0.218 & 0.111 & 0.038 & 0.139 & 0.853 & 0.167 & 0.0014 & 0.022 & 0.026 & 0.0020 \\
\hline $\mathbf{S E M} \pm$ & 0.0033 & 0.0044 & 0.0244 & 0.0292 & 0.0026 & 0.0328 & 0.0692 & 0.1097 & 0.0013 & 0.003 & 0.003 & 0.0019 \\
\hline $\operatorname{LSD}(P=0.05)$ & 0.01 & 0.01 & NS & $\mathrm{NS}$ & $\mathrm{NS}$ & NS & 0.19 & NS & $\mathrm{NS}$ & NS & NS & NS \\
\hline \multicolumn{13}{|c|}{ Fertilizer doses } \\
\hline F1 & 1.091 & 1.377 & 0.243 & 0.166 & 0.029 & 0.090 & 0.880 & 0.138 & -0.0032 & 0.0209 & 0.0293 & 0.0022 \\
\hline F2 & 1.117 & 1.460 & 0.217 & 0.134 & 0.037 & 0.104 & 0.999 & 0.107 & 0.0013 & 0.0177 & 0.0296 & 0.0015 \\
\hline F3 & 1.148 & 1.520 & 0.221 & 0.093 & 0.039 & 0.197 & 1.033 & 0.078 & 0.0021 & 0.0258 & 0.0253 & 0.0005 \\
\hline F4 & 1.171 & 1.581 & 0.212 & 0.101 & 0.041 & 0.236 & 1.026 & 0.145 & 0.0028 & 0.0272 & 0.0232 & 0.0012 \\
\hline SEM \pm & 0.0049 & 0.0057 & 0.0262 & 0.0296 & 0.0039 & 0.0219 & 0.0576 & 0.1664 & 0.0018 & 0.0026 & 0.0018 & 0.0019 \\
\hline $\operatorname{LSD}(P=0.05)$ & 0.0103 & 0.0119 & NS & NS & 0.0081 & 0.0461 & NS & NS & 0.0038 & 0.0055 & 0.0038 & NS \\
\hline
\end{tabular}


as well as soil fertility also. Findings are similar with Karunakaran and Behera (2015). They reported that reported that agricultural residues are retained on or near the soil surface reduce soil erosion, runoff of surface water, summer time soil temperatures and enhance water retention. All these factors, help to increase plant height of plant which in turns enhances the absolute growth rate Lower absolute growth rate $(1.377 \mathrm{~cm} /$ day $)$ was recorded with $25 \%\left(\mathrm{~F}_{1}\right)$ dose of fertilizers.

Crop Growth Rate: Crop growth rate was significantly affected by different tillage treatments at 90 days after sowing only. Highest crop growth rate was recorded with $\mathrm{T}_{2}(1.169 \mathrm{~g} / \mathrm{plant} / \mathrm{day})$. This might be due to the better nutritional environment for the crop because of decomposition of plant residues in mulch plots. Among fertilizer doses, $100 \%$ recommended dose of fertilizer recorded significantly higher CGR ( $0.236 \mathrm{~g} / \mathrm{plant} / \mathrm{day})$ at 30 and 60 days after sowing followed by $75 \%$ ( 0.197 $\mathrm{g} /$ plant/day ) and $50 \%$ doses ( $0.104 \mathrm{~g} /$ plant/day). Balanced dose of nutrients help in better growth and development of plants. Improved root and shoot growth ultimately increased the dry matter, resulting in higher value of crop growth rate.

Relative Growth Rate: Different tillage treatments did not affect the relative growth rate significantly. Among different fertilizer doses, $100 \%$ recommended dose of fertilizer significantly recorded higher relative growth rate $(0.0272$ $\mathrm{g} / \mathrm{g} /$ day $)$ followed by $75 \%(0.0258 \mathrm{~g} / \mathrm{g} /$ day $)$ at 30 and 60 days after sowing. Optimum dose of fertilizer helps in normal growth and development of plant. After 90 days, relative growth rate slightly decreased. Findings are same with Manhas et al.

\section{References}

Anonymous. 2018

$5-2-2021$ https://www.aps.dac.gov.in/APY/Public Report1.aspx

Anonymous.2019.Soybean monitor/ market watch. ICARIndian Institute of Soybean Research, Indore .pp: 1-11.

Anonymous.2021. http:/www.cropweatheroutlook.in/crida/amis/bramis.jsp

Karunakaran, V., \& Behera, U. K. (2015). Conservation agriculture in soybean (Glycine max)-wheat (Triticum aestivum) cropping system-A review. Agricultural Reviews, 36(3), 169-183.
(2019). They reported that $100 \%$ recommended dose of fertilizer, helps the plant to complete its lifecycle without any deficiency and provide normal growth and development to the plant.

Dry matter efficiency and Unit area efficiency: Different tillage practices significantly affected the dry matter efficiency and unit area efficiency of soybean. Highest dry matter efficiency of soybean was reported with $\mathrm{T}_{2}(0.275 \%$ /day $)$ followed by $\mathrm{T}_{3}$ $(0.271 \% /$ day $)$ and $\mathrm{T}_{1}(0.237 \%$ /day $)$ respectively. Unit area efficiency was also higher with $\mathrm{T}_{2}(9.34$ $\mathrm{kg} / \mathrm{ha} /$ day $)$ followed by $\mathrm{T}_{3}(8.86 \mathrm{~kg} / \mathrm{ha} /$ day $)$ and $\mathrm{T}_{1}$ $(6.94 \mathrm{~kg} / \mathrm{ha} /$ day $)$. Different fertilizer doses did not affect the dry matter efficiency but significantly affected the unit area efficiency. $\mathrm{F}_{4}$ treatment recorded significantly higher unit area efficiency $(8.81 \mathrm{~kg} / \mathrm{ha} /$ day $)$ followed by $\mathrm{F}_{3}(8.55 \mathrm{~kg} / \mathrm{ha} /$ day $)$ and $F_{2}(8.17 \mathrm{~kg} / \mathrm{ha} /$ day $)$. Significantly lower unit area efficiency $\left(8.00 \mathrm{~kg} / \mathrm{ha} /\right.$ day) was reported in $F_{1}$ treatment. This might be due to balanced application of nutrients. Similar results were found by Swati and Singh (2018) in soybean.

\section{Conclusion}

From the above study it may be concluded that the research on conservation agriculture is a need of the hour. Farmer generally prefers clean cultivation and thus goes for conventional agriculture without caring about its ill effects. Conservation agriculture is a sustainable way alternative for maintaining soil resource base. In the present study, the results showed that minimum tillage + crop residue@ $3 \mathrm{t}$ $\mathrm{ha}^{-1}$ along with $100 \%$ recommended dose of fertilizer resulted in higher growth and growth indices.

Manhas, S., Singh, J., Rana, K., \& Kaur, N. (2019). Evaluation of blackgram genotypes (Vigna mungo) under maize based intercropping systems. Indian Journal of Agricultural Sciences, 90(2), 444-448.

Mathew, R. P., Feng, Y., Githinji, L., Ankumah, R., \& Balkcom, K. S. (2012). Impact of no-tillage and conventional tillage systems on soil microbial communities. Applied and Environmental Soil Science, 2012.

Package of practices, kharif. 2019. Choudhary Sarwan Kumar Himachal Pradesh KrishiVishvavidyalya, Palampur, Himachal Pradesh- 176062. p. 69. 
Radford, P. J. (1967). Growth analysis formulae-their use and abuse 1. Crop science, 7(3), 171-175.

Sikka, R., Deol, J. S., Kaur, J., \& Singh, D. (2018). Effect of sowing dates, mulching and seed rates on nutrient uptake and productivity of soybean in sub-humid Punjab, India. Legume Research-An International Journal, 41(5), 750-754.

Singh, A.K., Singh, C.S. \& Singh, A.K.(2018). Enhancing Productivity and Quality of Soybean through Mulching and Anti-Transpirants in Jharkhand, India.International
Journal of Current microbiology and Current Sciences, (7), 4268-4272.

Swati., \& Singh, J.(2018). Productivity and profitability of Soybean (Glycine $\max$ L.) as influenced by different fertility levels and seed rate under mid hill conditions of Himachal Pradesh. Indian Journal of Agronomy, 63(3), 388-390.

Watson, D. J. (1956). Leaf growth in relation to crop yield FL Milthrope. The growth of leaves. London, Butterworth. 